\title{
The Myths of Textualism and Their Relevance To the ALI's Restatement of the Law, Copyright
}

\author{
Jon O. Newman*
}

In 2015, Justice Elena Kagan famously proclaimed, "We're all textualists now." To which I ask, "When were we not?"

Justice Kagan not only used the word "now," but also provided her evidence that being a textualist is of recent vintage. She asserted that when she was at the Harvard Law School in 1983, the inquiry concerning a statute was "what should this statute be," rather than what do "the words on the paper say." And she attributed this inquiry to a "policy-oriented" approach with judges "pretending to be congressmen." 3

With respect, I cannot credit this evidence. I started my law school years thirty years earlier at Yale Law School, which reveled in its reputation for being concerned with "policy," yet I never once heard a professor suggest that the text of a statute should be ignored in favor of a "policy" interpretation. "Policy" was thought relevant when a statutory provision was unclear, or, in nonstatutory cases, when existing case law provided no clear answer. Of course, even in a statutory case, the policy to be implemented was the policy preferred by Congress, not by judges.

I take on the task of refuting Justice Kagan because I believe the "now" in her statement is only one of many myths about textualism, myths often perpetuated by some judges, legal scholars, and politicians, especially when they disagree with a court's decision. Refuting these myths is particularly relevant to the current controversy within the American Law Institute concerning the effort to craft a Restatement of the Law, Copyright.

\section{TEXTUALISM}

I turn first to the many myths about textualism, the first of which is that only since the arrival of Justice Scalia at the Supreme Court have federal judges focused on

* Senior Judge, United States Court of Appeals for the Second Circuit.

1. Harvard Law School, The Antonin Scalia Lecture Series: A Dialogue with Justice Elena Kagan on the Reading of Statutes, YOUTUBE (Nov. 25, 2015), https://perma.cc/56G2-V74A.

2. Id.

3. Id.

(C) 2021 Newman. This is an open access article distributed under the terms of the Creative Commons Attribution-NonCommercial-NoDerivatives License, which permits noncommercial use, distribution, and reproduction, provided the original author and source are credited, and the article is not changed. 
statutory text when interpreting a statute. Yet all federal judges (I have been one for forty-nine years) begin the task of interpreting a federal statute by examining the text of the relevant provision. And we have always done so. ${ }^{4}$ A Westlaw search for "We begin" in the same sentence as "text" yielded 1,869 federal court decisions. Substituting "We start" yielded an additional 259 decisions. Similar formulations would undoubtedly produce even more.

To test Justice Kagan's "now" timing of textualism, let's trace the lineage of the idea that interpretation of a statute must begin with the text and, if the text is clear, end at that point, except only if adherence to the literal text in the context of a particular case would yield an absurd result. My retrospective journey considers decisions of the Supreme Court, beginning with Arlington Central School District Board of Education v. Murphy. ${ }^{5}$ I start here because Arlington Central is an interesting recent example of a battle between brilliant Justices interpreting statutory text differently and, in the process, illustrating some myths about textualism. I consider this battle later in this Response; at the moment, Arlington Central will serve only to start the search for the origin of textualism.

In Arlington Central, the Court, quoting Hartford Underwriters Insurance Co. $v$. Union Planters Bank, said: "When the statutory 'language is plain, the sole function of the courts - at least where the disposition required by the text is not absurd - is to enforce it according to its terms." "Hartford Underwriters ${ }^{7}$ quoted most of these words from United States v. Ron Pair Enterprises, Inc. ${ }^{8}$ In Ron Pair, the Court said: "[W]here, as here, the statute's language is plain, 'the sole function of the courts is to enforce it according to its terms,", quoting Caminetti v. United States. ${ }^{9}$

Caminetti expressed the principle in these words: "It is elementary that the meaning of a statute must, in the first instance, be sought in the language in which the act is framed, and if that is plain, and if the law is within the constitutional authority of the lawmaking body which passed it, the sole function of the courts is to enforce it according to its terms." 10 Caminetti cited Lake County v. Rollins, which expressed the principle in these words:

4. See, e.g., Maslenjak v. United States, 137 S. Ct. 1918, 1924 (2017) ("We begin, as usual, with the statutory text." (emphasis added)); Phillips v. Marine Concrete Structures, Inc., 877 F.2d 1231, 1234 (5th Cir. 1989) (“As always, we start with the text of the statute." (emphasis added)).

5. 548 U.S. 291 (2006).

6. Id. at 296-97 (quoting Hartford Underwriters Insurance Co. v. Union Planters Bank, N.A., 530 U.S. 1, 6 (2000)). In Arlington Central, the Court rejected the contention that the word "costs" included the expense of hiring expert witnesses. Id. at 300 .

7. In Hartford Underwriters, the Court rejected the contention that a statute permitting a bankruptcy "trustee" to recover certain administrative expenses from property securing an allowed secured claim permitted an insurance company to recover unpaid insurance premiums from such property. See 530 U.S. at $5-6$.

8. 489 U.S. 235, 241 (1989).

9. Id. (quoting Caminetti v. United States, 242 U.S. 470, 485 (1917)).

10. Caminetti, 242 U.S. at 485 . In Caminetti, the Court rejected the contention that a statute punishing transportation of any woman in interstate commerce "for the purpose of prostitution or debauchery, or any other immoral purpose," Act of June 25, 1910, ch. 395, 61st Cong., 1st Sess., § 2, 36 Stat. 825 , should be interpreted to punish only "the traffic in women for gain," 242 U.S. at $484-85$, rather than to include transportation of a woman to become the defendant's "concubine and mistress." Id. at $483-85$. 
To get at the thought or meaning expressed in a statute, a contract, or a constitution, the first resort, in all cases, is to the natural signification of the words .... If the words convey a definite meaning, which involves no absurdity, nor any contradiction of other parts of the instrument, then that meaning, apparent on the face of the instrument, must be accepted .... 11

Lake County cited United States v. Fisher, in which a separate opinion expressed the principle in these words: "Where a law is plain and unambiguous, whether it be expressed in general or limited terms, the legislature should be intended to mean what they have plainly expressed, and consequently no room is left for construction." 12 That opinion cited several state court decisions.

So it turns out that interpreting a statute solely from its text, as long as that text is clear, is as old as the Nation. And the lineage of textualism reveals not only an adherence to clear text but also the exception for an interpretation that yields an "absurd" result. ${ }^{13}$ There's the first myth of textualism. It is not some new method of statutory interpretation. Judges start with text, and if the text is clear, that is where their task ends.

Justice Kagan is not alone in claiming that textualism is new. Ninth Circuit Judge Diarmuid F. O'Scannlain recently echoed her remark. After acknowledging that "any competent lawyer knows that when construing a statute one begins with the text," he continued, "I can assure you, however, that this was not always the case. For those of us who remember a time before Scalia, Justice Kagan's statement is a testament to the sea change the law has undergone in recent decades." 14

Judge O'Scannlain's evidence was more specific than Justice Kagan's law school recollection. He cited Yates v. United States as an example of the "focus on the actual text." 15

Yates is curious evidence for the claimed recent advent of textualism. Preliminarily, I wonder why Judge O'Scannlain emphasized the word "actual." Is there some other kind of text? But quibbling aside, Yates is a wonderful case for a

11. Lake County v. Rollins, 130 U.S. 662, 670 (1889). In Lake County, the Court rejected the contention that a state constitution's limit on the amount of a county's debt, Colo. Const., art $11, \S 6$, applied only to debts incurred for certain purposes. See id. at 672-74.

12. United States v. Fisher, 6 U.S. (2 Cranch) 358, 399 (1805) (separate opinion of Washington, J.). In Fisher, the Court rejected the contention that a statute giving the United States a preference in bankruptcy proceedings for debts of "any revenue officer, or other person," Act of Mar. 3, 1797, ch. 20, 4th Cong., 2d Sess., $\S 5,1$ Stat. 512, 515, was limited to debts of persons who were receivers of public money, i.e., persons holding positions like that of revenue officers. See id. at 395 . To be fair, I must acknowledge that in Fisher, Justice Washington added this qualification: "But if, from a view of the whole law, or from other laws in pari materia, the evident intention is different from the literal import of the terms employed to express it in a particular part of the law, that intention should prevail, for that in fact is the will of the legislature." Id. at 399. It is important to note, however, that Washington said he would be willing to depart from the "literal import of the terms employed" only by considering other text, i.e., "the whole law" or "other laws in pari materia." Id.

13. Arlington Central, 548 U.S. at 297; Hartford Underwriters, 530 U.S. at 6; Lake County, 130 U.S. at 670 (applying literal meaning that "involves no absurdity").

14. Diarmuid F. O'Scannlain, "We Are All Textualists Now": The Legacy of Justice Antonin Scalia, 91 ST. JOHN's L. REV. 303, 304 (2017).

15. Id. at 307 (quoting Yates v. United States, 135 S. Ct. 1074 (2015)). 
discussion of textualism because it admirably illustrates other myths about the concept, in addition to the claim that starting with text is of recent origin.

In fact, it would be difficult to imagine facts that better illustrate these myths than those that led to the conviction of John Yates, captain of the Miss Katie, a commercial fishing boat. Captain Yates caught undersized red grouper in federal waters in the Gulf of Mexico. After a federal inspector saw the undersized fish and left them in crates on Yates's boat, a crew member threw them overboard at Yates's direction. Yates was indicted for "destroying, concealing, and covering up undersized fish to impede a federal investigation" in violation of 18 U.S.C. $\S 1519 .{ }^{16}$

Section 1519 authorizes imprisonment for up to twenty years for anyone who "knowingly alters, destroys, mutilates, conceals, covers up, falsifies, or makes a false entry in any record, document, or tangible object" with the intent to obstruct a federal investigation. ${ }^{17}$ Yates was convicted and sentenced to thirty days for violating $\S 1519 .{ }^{18}$ The issue before the Supreme Court was whether a fish was a "tangible object" within the meaning of $\$ 1519$. On that issue, the dueling opinions of Justices Ginsburg and Kagan not only reached opposite results, but also provided considerable insight into what textualism is and what it is not. And not surprisingly, when intellectually and linguistically talented jurists like these two do battle, the fray is both informative and fun to read. ${ }^{19}$

In the plurality opinion of Justice Ginsburg, joined by Chief Justice Roberts and Justices Breyer and Sotomayor, Justice Ginsburg began by looking at text, specifically the words "tangible object." She then resorted to a dictionary definition to acknowledge that "[t]he ordinary meaning of an 'object' that is "tangible" is " a discrete . . thing' . . that 'possess[es] physical form." ${ }^{20}$ She then stated: "Whether a statutory term is unambiguous, however, does not turn solely on dictionary definitions of its component words." Rather, "[t]he plainness or ambiguity of statutory language is determined [not only] by reference to the language itself, [but as well by] the specific context in which that language is used, and the broader context of the statute as a whole." 21 And, she added, "[i]n law as in life ... the same words, placed in different contexts, sometimes mean different things." 22

16. Yates, $135 \mathrm{~S}$. Ct. at 1080.

17. 18 U.S.C. $\$ 1519$ (emphasis added).

18. The sentence was imposed for the $\S 1519$ violation and a violation of 18 U.S.C. $\S 2232(a)$, punishing anyone who, "during, or after" an authorized search for property, "take[s] any action, for the purpose of preventing or impairing the Government's lawful authority to take such property into its custody." The maximum penalty for violating $\S 2232(a)$ is five years. Yates did not challenge his $\S 2232$ (a) violation.

One may speculate why the Government also charged the $\S 1519$ violation when $\S 2232(a)$ unquestionably applied to Captain Yates's conduct. Adding a count charging violation of a statute with a higher maximum penalty to increase the pressure for a guilty plea comes readily to mind.

19. For example, after pointing out that a Senate report rejected overly technical distinctions, Justice Kagan wrote, “Ah well: Congress, meet today's Court, which here invents just such a distinction with just such an effect." Yates, 135 S. Ct. at 1094 (Kagan, J., dissenting).

20. Yates, $135 \mathrm{~S}$. Ct. at 1081 (quoting Object, WEBSTER's THIRD NEW INTERNATIONAL DICTIONARY 1955 (2002) and Object, BLACK's LAW DiCTIONARY 1683 (10th ed. 2014)).

21. Id. at 1081-82 (brackets in original; internal quotation marks omitted).

22. Id. at 1082 . 
Here, Justice Ginsburg exposes another myth claimed for textualism-that focusing only on the words of a statute always yields the meaning Congress intended. As she illustrates with several examples, the same words in some statutes have different meanings in different contexts. ${ }^{23}$ Which of various meanings did Congress intend "tangible object" to have? Further inquiry is required. Moreover, resort to a dictionary will not always reveal what Congress intended by the words used because a dictionary often provides more than one definition of a word, and different dictionaries sometimes differ in their definitions. It was Learned Hand, no freewheeling disparager of adhering to statutory text, who famously said that "it is one of the surest indexes of a mature and developed jurisprudence not to make a fortress out of the dictionary." 24

After recognizing that what the words "tangible object" mean in $\S 1519$ could not be determined from a dictionary, Justice Ginsburg considered the context in which the words appear. The broadest aspect of that context was the fact that $\S 1519$ was a section of the Sarbanes-Oxley Act of 2002 ("Sarbanes-Oxley"), ${ }^{25}$ a statute, she noted, "designed to protect investors and restore trust in financial markets following the collapse of Enron Corporation." 26 A more particular aspect of context was the caption of $\S 1519$ : "Destruction, alteration, or falsification of records in Federal investigations and bankruptcy." ${ }^{27}$ Another aspect of context was the title of $\S 802$ of Sarbanes-Oxley, which added $\S 1519$ to Title 18 of the United States Code. The title of $\S 802$ is "Criminal Penalties for Altering Documents." And, she noted, the only other addition to Title 18 made by $\S 802$, that is, $\S 1520$, is titled "Destruction of corporate audit records." Acknowledging that "headings are not commanding," she said that "they supply cues ${ }^{28}$ that Congress did not intend 'tangible object' in $§ 1519$ to sweep within its reach physical objects of every kind, including things no one would describe as records, documents, or devices closely associated with them." 29

Justice Ginsburg then invoked two canons of statutory interpretation, regrettably known by their Latin versions: noscitur a sociis, which she loosely translated as, "a word is known by the company it keeps, ${ }^{, 30}$ and ejusdem generis, which she explained means, "[W]here general words follow specific words in a statutory enumeration, the

23. As examples, Justice Ginsburg cited decisions stating that the following words had different meanings in different provisions of some statutes: "located," Wachovia Bank, N.A. v. Schmidt, 546 U.S. 303, 313-14 (2006) (different provisions of the National Bank Act); "age," Gen. Dynamics Land Sys., Inc. v. Cline, 540 U.S. 581, 595-97 (2004) (different provisions of the Age Discrimination in Employment Act of 1967); or different meanings in some sections or titles: "employee," Robinson v. Shell Oil Co., 519 U.S. 337, 342-44 (1997) (different sections of Title VII of the Civil Rights Act of 1944); "wages paid," United States v. Cleveland Indians Baseball Co. 532 U.S. 200, 213 (2001) (different provisions of Title 26 of the U.S. Code).

24. Cabell v. Markham, 148 F.2d 737, 739 (2d Cir. 1945). Judge Hand also said that "words are chameleons, which reflect the color of their environment." Comm'r of Internal Revenue v. Nat'l Carbide Corp., 167 F.2d 304, 306 (2d Cir. 1948).

25. Sarbanes-Oxley Act of 2002, 116 Stat. 745 (2002).

26. Yates, 135 S. Ct. at 1079.

27. Id. at 1083 .

28. Possibly "clues." Word's spellcheck feature is not perfect.

29. Yates, 135 S. Ct. at 1083.

30. Id. at 1085 . 
general words are [usually] construed to embrace only objects similar in nature to those objects enumerated by the preceding specific words." 31 The first canon, she contended, indicates that in $\S 1519$ 's list of “any record, document, or tangible object," the last term is "appropriately read to refer, not to any tangible object, but specifically to the subset of tangible objects involving records and documents, i.e., objects used to record or preserve information.",32

The second canon, she contended, also indicates that "tangible object" should be understood to have a meaning similar to that of the preceding words "record" and "document": "Had Congress intended 'tangible object' in $\S 1519$ to be interpreted so generically as to capture physical objects as dissimilar as documents and fish, Congress would have had no reason to refer specifically to 'record' or 'document.' The Government's unbounded reading of 'tangible object' would render those words misleading surplusage." 33

Finally, Justice Ginsburg invoked the interpretive principle that "ambiguity concerning the ambit of criminal statutes should be resolved in favor of lenity." 34 For all of these reasons, the plurality opinion for four Justices held "that a "tangible object' within $\S 1519$ 's compass is one used to record or preserve information," i.e., not fish. ${ }^{35}$ Justice Alito, whom most would regard as a dedicated textualist, supplied the fifth vote to support the Court's judgment reversing Captain Yates's $§ 1519$ conviction. $^{36}$

This account of the majority's reasons for rejecting the literal meaning of "tangible object" in $\S 1519$ reveals another myth about textualism. The myth is that once a judge declines to apply the dictionary meaning of a statutory word or phrase, the judge turns immediately to legislative history to discern the legislators' purpose and, hence, the meaning of the word or phrase at issue. Neither Justice Ginsburg nor Justice Alito cited any of the traditional sources of legislative history-committee reports and floor debates - to support their reasoning. ${ }^{37}$ After recognizing that the dictionary definitions of the words at issue were an unreliable guide to their meaning in $\S 1519$, they looked to the context in which the words were used and enlisted

31. Id. at 1086 (brackets in original) (quoting Wash. State Dep't of Soc. Health Servs. v. Guardianship Est. of Keffeler, 537 U.S. 371, 384 (2003)).

32. Id. at 1085 .

33. Id. at 1087 .

34. Id. at 1088 (quoting Cleveland v. United States, 531 U.S. 12, 25 (2000)).

35. Id. at $1088-89$.

36. Id. at 1089 (Alito, J., concurring). Justice Alito's brief opinion relied primarily on the noscitur a sociis and ejusdem generis canons, contending that the nouns of $\S 1519$, "record," "document," and "tangible object" should be given a similar meaning and that the last phrase in the list of verbs, "alters, destroys, mutilates, conceals, covers up, falsifies, or makes a false entry in," "makes no sense outside of filekeeping. How does one make a false entry in a fish?" Id. at 1090 (Alito, J., concurring).

37. Justice Ginsburg considered the Government's claim that the origin of the words "record, document, or tangible object" supported its broad interpretation of $\S 1519$ to include fish. See id. at 108788. The Government contended that this sequence of words first appeared in a provision of the 1962 Model Penal Code ("MPC") that prohibited various ways of tampering with any kind of physical evidence. She rejected the significance of the MPC, pointing out that "the MPC provision did not prohibit actions that specifically relate to records, documents, and objects used to record or preserve information." Id. at 1087. 
traditional canons of statutory interpretation to support their narrow interpretation of the words.

Justice Kagan disagreed with the Court's decision, reaching what she called a "conventional result: A 'tangible object' is an object that's tangible." 38 But that is not interpretation; it is tautology. Ignored is the legitimate inquiry as to what "tangible object" means as used in $\$ 1519$. Nevertheless, her dissenting opinion, joined by Justices Scalia, Kennedy, and Thomas, merits consideration because, like Justice Ginsburg's opinion, it reveals interesting aspects of textualism.

Justice Kagan began by pointing out that the "ordinary meaning" of "tangible object" is, as the plurality opinion acknowledged, "a discrete thing that possesses physical form." 39 "A fish," she pointed out, is "a discrete thing that possesses physical form." ${ }^{40}$ As authority, she cited the well-known ichthyologist, Dr. Seuss, and his 1960 book, One Fish Two Fish Red Fish Blue Fish. ${ }^{41}$ She also pointed out that many statutes use the words "tangible objects," and in those statutes, courts have not narrowed the meaning to "exclude things that don't record or preserve data." 42

Then, however, she acknowledged: "That is not necessarily the end of the matter; I agree with the plurality (really, who does not?) that context matters in interpreting statutes.... And sometimes that means, as the plurality says, that the dictionary definition of a disputed term cannot control." 43 Thus, another myth of textualism: Even the proclaimer of " $[\mathrm{w}] \mathrm{e}$ 're all textualists now" does not end the inquiry with a dictionary but considers the context in which statutory words are used.

Justice Kagan continued with a point-by-point response to each of Justice Ginsburg's reasons for reading "tangible object" in $\S 1519$ narrowly. She considered the other words of $\S 1519$; the claimed lack of relationship between the section's nouns and verbs; the title of the section; the way the words "record, document, or other object" have been broadly interpreted in what she considered an analogous statute, 18 U.S.C. $\S 1512$ (prohibiting witness tampering); and canons of statutory interpretation. ${ }^{4}$

Justice Kagan also considered legislative history, "for those who care about it." Asserting that $\S 1519$ "began its life in a separate bill," which became 18 U.S.C. $\S 1512$, she cited a Senate report, S. Rep. 107-146 (2002), on that bill, which she contended has helpful language on the meaning of $\S 1519 .{ }^{46}$ She also cited action on the Senate floor in which then-Minority Leader Trent Lott introduced an amendment to $\S 1512$ and noted Lott's floor remarks on the overlap between $\S \S 1512$

38. Id. at 1091 (Kagan, J., dissenting).

39. Id. (Kagan, J., dissenting) (quoting plurality opinion, $i d$. at 1081).

40. Id. (Kagan, J., dissenting).

41. Although often rendered with commas, the title has no commas.

42. Id. at 1092 (Kagan, J., dissenting).

43. Id. (Kagan, J., dissenting).

44. See id. at 1091-1100 (Kagan, J., dissenting).

45. Id. at 1093 (Kagan, J., dissenting).

46. Id. (Kagan, J., dissenting). 
and $1519 .{ }^{47}$ This legislative history, Justice Kagan said, "puts extra icing on a cake already frosted." 48

It is not my purpose in this Response to choose sides in the interesting Ginsburg/Kagan debate. I have explored their opinions in Yates because of the myths they reveal about textualism: (1) that starting statutory interpretation with examination of text is new; (2) that ending statutory interpretation when statutory text is clear is also new; (3) that a word with a clear meaning in ordinary conversation probably has that same clear meaning in a statute; (4) that the meaning of statutory words can usually be determined from a dictionary; (5) that the context in which ambiguous statutory words and phrases are used is often not relevant; (6) that other words in the statutory provision at issue, the words in other provisions in the same or other statutes, the title of a statute, and traditional canons of statutory construction often need not be considered to determine the meaning of ambiguous words and phrases; and (7) that legislative history should rarely (some say never) be considered to determine the meaning of ambiguous words and phrases of a statute. ${ }^{49}$

Admittedly, not all of these myths are always proclaimed by all judges who march under the banner of textualism. Although, as I have said, all judges start statutory interpretation by examining text, many do not end their task at that point. In some cases, many recognize that a word or phrase that has a clear meaning in ordinary conversation does not necessarily have a clear meaning in a particular statute, and the interpretive task is always to determine the meaning in the statute at issue. ${ }^{50}$ And in cases where all agree that the meaning is not clear, judges sometimes consult a dictionary and consider context, other provisions of the statute, provisions of other statutes, canons of statutory construction, and, yes, legislative history.

Whether legislative history is an appropriate source of the meaning of ambiguous statutes is, of course, the major issue in today's debate about textualism. ${ }^{51}$ At one extreme is Justice Scalia, who flatly rejected the use of legislative history: "[O]nly the text Congress voted on, and not unapproved statements made or comments written during its drafting and enactment process, is an authoritative indicator of the law." 52 Yet, even Justice Scalia was not quite the absolutist he claimed to be. In Green v. Bock Laundry Machine Co., Justice Scalia stated:

47. Id. at 1096 (Kagan, J., dissenting)

48. Id. at 1093 (Kagan, J., dissenting).

49. One scholar has referred to the age-old idea that "once the Court has ascertained a statute's plain meaning, consideration of legislative history becomes irrelevant," as "the new textualism." William N. Eskridge Jr., The New Textualism, 37 UCLA L. REV. 621, 623 (1990).

50. I am not one to complain that Congress sometimes uses an ambiguous word or phrase in a statute. Often many members of Congress are united in their support of a bill's purpose and their determination to see it enacted, but sharply divided on important details. Only the deliberate use of ambiguous language will bridge the divide. Many years ago, it was part of my assignment as a Senate staffer to come up with such language.

51. Occasionally some Justices have used legislative history to confirm their view that what they understood to be the clear meaning of text was in fact what Congress intended. See James J. Brudney, Confirmatory Legislative History, 76 BROOK. L. REV. 901 (2011).

52. Carr v. United States, 560 U.S. 438, 458 (2010) (Scalia, J., concurring). 
I think it entirely appropriate to consult all public materials, including the background of Rule 609(a)(1) [of the Federal Rules of Evidence] and the legislative history of its adoption to verify that what seems ... an unthinkable disposition ... was indeed unthought of, and thus to justify a departure from the ordinary meaning of the word "defendant" in the Rule. ${ }^{53}$

He did not explain why legislative history was useful to determine what Congress did not intend but not to determine what Congress did intend. ${ }^{54}$

Near to Justice Scalia, but not quite endorsing his condemnation, is Justice Thomas, who sometimes is content to decline to join parts of a Supreme Court opinion that cite legislative history, noting, for example, that "the Court's textual analysis is sufficient to resolve the case." ${ }^{55}$ Not quite so opposed to legislative history is Justice Alito; noting, for example, "I think that the citations to legislative history are of little if any value here." 56

The "sea change" that Judge O'Scannlain perceived to have occurred with the arrival of Justice Scalia is admittedly at least a decline in the Justices' use of legislative history, ${ }^{57}$ but hardly the elimination or even the near elimination of it. Federal judges (textualists "all" as Justice Kagan says) frequently continue to consider relevant congressional committee reports and sometimes floor colloquy to determine how Congress wanted an ambiguous word or phrase of a statute to be understood. Indeed, the use of legislative history has been endorsed, significantly, by leading members of Congress itself. ${ }^{58}$ The case for continuing to use legislative

53. 490 U.S. 504, 527 (1989) (Scalia, J., concurring) (emphasis added).

54. A colloquy on the use of legislative history I had with Justice Scalia at a meeting of the Federal Judges Association in Washington, D.C. in May 2014 included the following:

Judge Newman: "Justice Scalia, let me offer what I think is the easiest case. A statute has a phrase that all agree is ambiguous. The relevant Senate committee report on the bill that became the statute considers the precise issue posed by a pending case and provides the committee's answer. Why shouldn't a court place at least some reliance on that legislative history?" Justice Scalia: "Why should it?"

Judge Newman: "Because it represents the view of the Senators most knowledgeable about the bill that became the statute." Justice Scalia: "All members of Congress didn't read the report."

Judge Newman: "All members of Congress didn't read the statute either."

55. See Samantar v. Yousuf, 560 U.S. 305, 326 (2010) (Thomas, J., concurring).

56. Id. (Alito, J., concurring).

57. See, e.g., James J. Brudney \& Corey Ditslear, The Decline and Fall of Legislative History? Patterns of Supreme Court Reliance in the Burger and Rehnquist Eras, 89 JUDICATURE 220, 220 (2006) (reporting a decline, in the period 1986-2006, from nearly fifty to less than thirty percent of the number of majority opinions concerning workplace law that cited legislative history). Another study reports a larger decline, but overstates the situation by counting the number of legislative history citations, not the decisions citing such history. See Michael H. Koby, The Supreme Court's Declining Reliance on Legislative History: The Impact of Justice Scalia's Critique, 36 HARV. J. ON LEGIS. 369, 384 (1999). It is not surprising that opinions that consider legislative history relevant would include more than one example in interpreting a single statue.

58. See, e.g., Nomination of Judge Antonin Scalia: Hearings Before the S. Comm. on the Judiciary on the Nomination of Antonin Scalia, To Be Associate Justice of the Supreme Court of the United States, 99th Cong. 65-66 (1986) (Statement of Sen. Charles E. Grassley) ("[A]s one who has served in Congress for 12 years, legislative history is very important to those of us here who want further detailed expression of . . . legislative intent."); Senator Orrin Hatch, Legislative History: Tool of Construction or Destruction, 11 HARV. J.L. \& PUB. POL'Y 43, 47 (1988) ("The legislative history ... imparted the additional 
history to divine Congressional meaning of ambiguous statutes so that they will be interpreted to advance Congress's purpose has recently been persuasively argued in Judge Robert Katzmann's highly regarded book, Judging Statutes.

\section{LEGISLATIVE HISTORY AND THE ALI'S CURRENT DRAFTING OF A RESTATEMENT OF COPYRIGHT LAW}

The myths of textualism and the unjustified reluctance of some to use legislative history are brought into sharp focus by the current controversy within the American Law Institute (ALI) as it considers publishing a Restatement of the Law, Copyright ("Copyright Restatement").

The project was announced in 2014. ${ }^{59}$ All those associated with the project- - the Reporter, ${ }^{60}$ the four Associate Reporters, ${ }^{61}$ the Advisers, ${ }^{62}$ and those commenting on preliminary steps in the project - have recognized that this ALI Restatement will differ from most Restatements because it concerns a field of law dominated by a federal statute, the Copyright Act of 1976 ("the Act"). ${ }^{63}$ Most Restatements, such as those on contracts ${ }^{64}$ and torts, ${ }^{65}$ concern fields developed at common law, supplemented by state statutes. However, this is not the first time that the ALI has undertaken a Restatement in the shadow of a federal statute. Chapter 3 of the Restatement (Third) of Unfair Competition, concerning trademarks, explicates many of the provisions of the Lanham Act, ${ }^{66}$ and the Restatement (Fourth) of the Foreign Relations Law of the United States performs a similar task with respect to some sections of the Foreign Sovereign Immunities Act. ${ }^{67}$

Unlike the ALI's consideration of trademark law or foreign relations law, the current project on copyright law has precipitated controversy over how the Copyright Restatement should interpret the relevant federal statute. The controversy implicates at least three of the myths of textualism: that a word with a clear meaning in ordinary conversation probably has that same clear meaning in a statute; that the meaning of statutory words can usually be determined from a dictionary; and that legislative history should rarely (some say never) be considered to determine the meaning of

\footnotetext{
information necessary to preserve the basic goal of pretrial detention."); Joan Biskupic, Scalia Takes a Narrow View in Seeking Congress' Will, 48 CONG. Q. WKLY. REP. 913, 917 (1990) (“I think when justices disregard [legislative history], it is just another way to write their own law ...." (quoting statement of Senator Arlen Specter)).

59. Four New Projects to Begin in 2015, 37 A.L.I. REP. 1, 1 (Fall/Winter 2014).

60. Prof. Christopher Jon Sprigman.

61. Profs. Daniel J. Gervais, Lydia Pallas Loren, Anthony Reese, and Molly S. Van Houweling.

62. The forty-seven Advisers are listed in June M. Besek, Peter S. Menell, Irene Calboli, Devlin Hartline, Justin Hughes, Pierre N. Leval, and William F. Patry, The ALI Copyright Restatement Project: A Horse of a Different Color?, Proceedings of the Twenty-Sixth Annual Conference International Intellectual Property Law \& Policy, Fordham University School of Law Skadden Conference Center, New York, New York, April 6, 2018, at 3 n.3.

63. 17 U.S.C. $\S \S 101-810$.

64. RestateMENT (SECOND) OF CONTRACTS (AM. L. INST. 1981).

65. RESTATEMENT (THIRD) OF TORTS: LIABILITY FOR ECONOMIC HARM (AM. L. INST. 2020).

66. 15 U.S.C. $\S 1501$ et seq.

67. 28 U.S.C. $\S \S 1330,1332,1391(\mathrm{f}), 1441(\mathrm{~d}), 1602-11$.
} 
ambiguous words and phrases of a statute. The controversy concerns two issues: (1) the narrow issue of how particular text of the Copyright Act should be interpreted; and (2) the broader issue of how all the text of the Act should be displayed in a Copyright Restatement.

\section{A. Particular Text}

To illustrate the controversy over particular text, I consider the word "distribute" in $\S 106(3)$ of the Act: "[T] he owner of copyright ... has the exclusive rights . . . (3) to distribute copies or phonorecords ... of the copyrighted work to the public by sale or other transfer of ownership, or by rental, lease, or lending." ${ }^{.68}$ As a matter of ordinary conversation, the meaning seems clear: A person distributes things by handing them out to others. But as with many copyright issues, the meaning of "distribute" in $\S 106(3)$ is not so clear in the digital age.

Uncertainty arose with internet file sharing of sound recordings. Copyright owners typically contended broadly that a file, obtained from publicly accessible fileshare folders, was distributed as soon as it was made available for sharing. File sharers typically contended narrowly that a file was not distributed until it was not only made available for sharing but also downloaded by a third party. The ordinary conversational meaning of "distribute" seemed to favor the broad meaning. But what was the meaning of "distribute" as used in $\S 106(3)$ ? Courts reached different conclusions. ${ }^{69}$ Their disagreement alone is reason enough not to accept the ordinary conversational meaning of "distribute." And enormous economic consequences turn on the outcome of the dispute. ${ }^{70}$

Starting with a dictionary does not resolve the matter. The online Merriam Webster dictionary, for example, provides three meanings, ${ }^{71}$ none of which is pertinent to § 106(3). So where's the answer?

One noted copyright scholar, Professor Peter Menell, undertook a meticulous inquiry, using all the tools of statutory interpretation. ${ }^{72}$ Like all textualists, he made a detailed analysis of the text of $\S 106(3){ }^{73}$ Finding no clear meaning in the word

68. 17 U.S.C. $\S 106(3)$.

69. Compare Capitol Recs. Inc. v. Thomas, 579 F. Supp. 2d 1210, 1218 (D. Minn. 2008) (“[A]ctual distribution or dissemination is required in $\S 106(3)$.”), with Interscope Recs. v. Duty, No. 05-CV-3744PHX-FJM, 2006 U.S. Dist. LEXIS 20214, at *4 (D. Ariz. Apr. 14, 2006) (“[T]he mere presence of copyrighted sound recordings in [defendant's] share file may constitute copyright infringement.").

70. Peter Menell, In Search of Copyright's Lost Ark: Interpreting the Right to Distribute in the Internet Age, 59 J. COPYRIGHT SOC'Y U.S.A. 7 (2011) [hereinafter Menell, Copyright's Lost Ark] ("Based upon the Digital Theft Deterrence and Copyright Damages Improvement Act of 1999, the range of potentially recoverable statutory damages for each infringed work extends to $\$ 150,000$. Thus, in a case alleging infringement of thirty works, the defendant faces potential exposure of $\$ 4.5$ million.") (footnote omitted).

71. Distribute, MERriam-WeBSTER.COM, https://perma.cc/L5DZ-DS6G (last visited Mar. 13, 2021) (Distribute: (1) "to divide among several or many"; (2)(a), (b) "to spread out ... or deliver especially to members of a group"; (2)(c) "to place or position so as to be properly apportioned over or throughout an area.")

72. See generally Menell, Copyright's Lost Ark, supra note 70.

73. Id. at 53-57. The consideration of the statutory text does not begin the article, although it is fair to say that it is the analytical starting point of Menell's search for the meaning of the text. 
"distribute" as used in $\S 106(3)$, indeed noting two significantly different meanings in the case law, he embarked on a broader search for clues as to the meaning Congress intended. A major point in this broader inquiry was the observation that the right to "distribute" in the 1976 Act replaced the two rights to "publish" and to "vend" in the 1909 Copyright Act. ${ }^{74}$ Having identified these precursors of the right to distribute, he considered: (1) the history of the right to "publish," going all the way back to the Copyright Act of $1790 ;{ }^{75}$ (2) the history of the right to "publish" in the 1909 Act; ${ }^{.6}$ (3) the development of the language that became $\S 106(3)$, beginning with the work of the Register of Copyrights in $1955 ;^{77}$ and (4) the enactment of the Sound Recording Amendments Act of 1971, ${ }^{78}$ and the Powers Clause of $\S 106$ of the 1976 Act. ${ }^{79}$ His conclusion: "[H]istory establishes beyond peradventure that Congress intended to broaden the historic rights to 'publish' in crafting the right to distribute," i.e., a sound recording is distributed when it is made available for copying. ${ }^{80}$

It is not my purpose to accept or reject Professor Menell's conclusion. Rather, I invite readers to see how serious scholarship can reveal many of the myths of textualism and use a variety of sources in a search for the likely congressional meaning of ambiguous statutory text.

\section{B. The Copyright Restatement And the TeXt of The ACt}

The controversy regarding the text of the Act concerns statements of black letter law, the bold-faced sentences of principles of law in all Restatements. ${ }^{81}$ The

74. Id. at 37. Copyright's Lost Ark does not actually start the extra-textual analysis with the language of the 1909 Act, but for simplicity, I have grouped Professor Menell's consideration of sources somewhat differently than does the article. Noticing that the word "distribute" is a change from the words used in the previous version of the Copyright Act is not an examination of a committee report or floor debate, the sources particularly condemned by Justice Scalia because not all members of Congress had read them. A provision of a prior statute and the same provision, differently worded in a current statute, are texts adopted by all members of Congress who voted for them (whether or not all read them). Why the words were changed is an entirely appropriate inquiry for a Court considering the meaning of the new words. Sometimes sources such as committee reports and floor debates shed at least some light on why the change was made. If not, it is still appropriate for a court to search all available sources of meaning, such as the wording of similar provisions and the context of the words, to determine an interpretation that best carries out the purpose Congress was endeavoring to achieve by making the change.

75. Id. at $32-37$.

76. Id. at $37-39$

77. Id. at 39-50.

78. Id. at $50-51$.

79. Id. at $60-63$.

80. Id. at $66-67$.

81. The term "black letter law" did not originate with the Restatements. An early, perhaps the first, use of the term in an American court's decision appeared in Shorner's Case, 22 F. Cas. 8, 9 (D. Pa. 1812) ("It is a cold and cheerless submission to and unnecessary extension of the rude and rigorous principles of black letter jurisprudence to say that because the mother is not entitled to, and cannot sue for amends for loss of service of the son (yet by the law of Pennsylvania he is obliged to assist in her support), she may not interfere in what regards his welfare and happiness."). In 1831, the Supreme Court said: "It is seldom that a case in our time savours so much of the black letter; but the course of decisions in New York renders it unavoidable ...." Bradstreet v. Huntington, 30 U.S. 402,434 (1831). The Court did not use the phrase "black-letter law" until 1959. See Romero v. Int'l Terminal Operating Co., 358 U.S. 354, 376-77 (1959) ("This lucid principle of constitutional construction, [that the Constitution considers 
Reporters use traditional black letter sentences to introduce each section of the Copyright Restatement. ${ }^{82}$ Some critics of this approach fear that this will denigrate the primacy of the text of the Act in understanding its meaning; they favor "beginning each section of the Copyright Restatement with a recitation of the applicable Copyright text rather than "black-letter law." 83

On this controversy, I do have a view. I suggest that the Copyright Restatement begin each section with both the relevant text of the Act, whenever such text applies to a particular section, and whatever black letter statement of law the drafters of the Restatement and ultimately the Council of the ALI deem appropriate for that section. The relevant text of the Act should be included in its entirety in the statement of black letter law (and placed first) in recognition of the dominant force of the Act in this area of law. ${ }^{84}$ But a statement of relevant black letter law should then be included in the beginning of each section in recognition of the customary purpose of Restatements to restate in clear terms the applicable law.

admiralty a distinct class of cases within federal courts' jurisdiction] ... had been treated as black-letter law in leading treatises."). See generally Shyamkrishna Balganesh, The "Black-Letter" Law of a Statute (unpublished manuscript) (on file with author); Kasia Solon Cristobal, From Law in Blackletter To “Blackletter Law," 108 LAW LIBR. J. 181 (2016).

82. See Restatement of the Law, Copyright (Am. L. Inst., Tentative Draft No. 1, Apr. 8, 2020)

83. Besek et al., supra note 62 , at 5 .

84. I acknowledge that this was not the course followed in other fields dominated by a statute. As one of the advisors to the Restatement of Unfair Competition, I do not recall that beginning statements of black letter law with the relevant text of the Lanham Act was even considered when trademark law was restated. In retrospect, I think it should have been. The failure to do so led to some inexplicable dissonance. For example, the Lanham Act provides:

(a) Civil action

(1) Any person who, on or in connection with any goods or services, or any container for goods, uses in commerce any word, term, name, symbol, or device, or any combination thereof, or any false designation of origin, false or misleading description of fact, or false or misleading representation of fact, which-

(A) is likely to cause confusion, or to cause mistake, or to deceive as to the affiliation, connection, or association of such person with another person, or as to the origin, sponsorship, or approval of his or her goods, services, or commercial activities by another person, or

(B) in commercial advertising or promotion, misrepresents the nature, characteristics, qualities, or geographic origin of his or her or another person's goods, services, or commercial activities,

shall be liable in a civil action by any person who believes that he or she is or is likely to be damaged by such act.

15 U.S.C. § 1125(a) (emphasis added).

The relevant black letter law of the Restatement provides:

One who, in connection with the marketing of goods or services, makes a representation relating to the actor's own goods, services, or commercial activities that is likely to deceive or mislead prospective purchasers to the likely commercial detriment of another under the rule stated in $\S 3$ is subject to liability to the other for the relief appropriate under the rules stated in $\S \S 35-37$.

RESTATEMENT (THIRD) OF UNFAIR COMPETITION $§ 2$ (AM. L. INST. 1995) (emphasis added). Why does the Restatement say "likely to deceive or mislead" when the Lanham Act says "likely to cause confusion, or to cause mistake, or to deceive?" 
There will likely be some sections of a Copyright Restatement where the Act has no relevant statutory text. As to such sections, a traditional statement of black letter law, setting forth what is understood to be the prevailing view of the case law, will be especially helpful.

Where statutory text is applicable to a particular section and substantial case law interpreting such text is divided, the drafters would do well to identify the alternate lines of authority in the black letter statement, augmenting the statement with appropriate comment. Care must be taken to restate the law, even with its uncertainties, rather than to prescribe a preferred interpretation of statutory text, unless the preference is grounded in a meticulous consideration of all pertinent sources of congressional meaning.

Preparing a restatement in a field of law dominated by a comprehensive statute presents special challenges. Those undertaking the task, textualists all, should proceed cautiously, avoiding the myths of textualism and endeavoring to implement congressional purpose at every turn, so that the Copyright Restatement will be a valuable addition to the ALI's preeminent series. 